\title{
Commentaries
}

\section{A dozen Danish cartoons and the wrath of the Muslim world}

How do we understand the outrage in the Muslim world against the 12 cartoons published in the Danish newspaper Jyllands-Posten? And can we move on from anger and misunderstanding? Is there room for dialogue?

PHILIP CASS

College of Communication and Media Sciences, Abu Dhabi

$\mathrm{I}$

T IS now several weeks since the Muslim world exploded with anger at a series of cartoons originally published in the Danish newspaper JyllandsPosten. The cartoons variously depicted the Prophet Mohammed as a terrorist and murderer, the best known of which shows him wearing a bomb as a turban. The cartoons were later re-published in a Norwegian evangelical newsletter. After they were first published a group of Danish imams approached the Danish courts, but were advised that there were no legal grounds for seeking redress. Subsequently, the imams traveled to the Middle East, taking with them a pamphlet in which they reproduced the newspaper cartoons, but added three more images which had been circulating on the internet and elsewhere. These images were entirely unrelated to the newspaper cartoons.

The three additional images included a photograph of a man wearing a pig mask, which has since been identified as having been taken at an agricultural fair in France some years ago. The other images included a crudely drawn cartoon figure and a photograph of a man being sodomised by a dog. It appears that many people thought the three additional images had been published by Jyllands-Posten and that it was these which aroused the greatest ire. ${ }^{1}$ Anger in the Muslim world has been expressed in violent demonstrations, attacks on Danish embassies and boycotts of Danish goods. In many cases the rioting has been used as a cover for attacks on the United States, its

148 PACIFIC JOURNALISM REVIEW 12 (1) 2006 
allies and local governments. This has been especially true in Pakistan, Iraq and Afghanistan, where extremists have whipped up mobs in order to serve their own ends. The weekly riots in Pakistan are as much a cover for antiMushareff sentiment as anything else.

Discussion of the issue has become increasingly dangerous. Not long after the controversy erupted, a lecturer at Zayed University's Dubai campus showed the cartoons to her class. There are conflicting versions of why this happened and what happened in the next 48 hours. What is certain is that the incident became widely known almost immediately and that a series of SMS messages of varying accuracy were texted around the country. The woman was sacked, as was her supervisor. The story was widely covered by the United Arab Emirates media and then picked up by international news agencies, including CNN and AFP. The latter ran an inflammatory story that appeared to be cobbled together from press releases from the Minister for Higher Education, Sheikh Nahayan, gossip and text messages. (Dubai sacks US Prof, 2006). The AFP story concluded with a quote from 'a mother', who preferred to remain anonymous, to the effect that she had been on her way to the university's Dubai campus to punish the woman because it was halal (approved by Allah) to kill people who insult the prophet.

Meanwhile, all Danish products, from butter to Lego, were taken off the shelves. Even Danish butter biscuits, which are actually made in England, vanished. Danish dairy products sell well here, their main rival being New Zealand's Anchor brand. However, shortly after three New Zealand daily papers printed the cartoons - the Dominion Post, The Press and The Nelson Mail-Anchor butter quietly vanished from the shelves (NZ newspapers spark criticism by publishing cartoons, 2006).

The UAE press devoted many pages to the controversy, with daily reports in the early stages of violent and fatal clashes in Pakistan and elsewhere. However, it has also carried calls from UAE officials for such demonstrations to end, saying they are counter-productive. The Gulf News went so far as to carry an article from the editor of the Jyllands-Posten explaining his newspaper's position. This was heralded as being a debate on the issue, but the next day the letters page was devoted entirely to letters attacking the Danes. (Professor and supervisor sacked, 2006).

So why have people died, embassies burned and Danish butter biscuits banished because of the publication of a few cartoons in an obscure Danish newspaper? I would like to suggest two answers: Firstly, there is undoubtedly 
widespread ignorance and insensitivity towards Islam in Europe. I would argue that this stems from the attempt to marginalise Christianity that have been going on in Western Europe since the second half of the 19th century and that disrespect for Islam is an inevitable outcome of this policy. If one cannot respect one's own religious traditions, how can you respect somebody else's?

For more than a century there has been a kulturkampf in Western Europe, with religion of any kind derided and marginalised and philosophy reduced to cheap Sartre. The intellectual classes and products of the écoles supérieures enthusiastically report that Europe is 'post-Christian', and do not bother to erect the 'temples of reason' that were flung up after 1788 in an attempt to provide a secular alternative to the church. Such contempt towards the church - and in particular Catholicism - has, I would argue, been the reason why many Europeans were so bewildered by the Muslim response to the cartoons. They no longer had an intellectual framework in which religion was understood, much less respected. The anger of the Muslim world was incomprehensible. In their defence, they fell back on secular arguments about freedom of expression and a right to criticise and satirise whatever they liked. To a Muslim world angered by whatever version of the cartoon controversy they had been given, such a defence was not just bewildering, but insulting.

When the Soviet empire collapsed, Francis Fukuyama famously and idiotically pronounced that history was at an end because from now on there would be no more changes and that capitalism and democracy had triumphed. History has proved him wrong, of course, just as it has proved and will keep proving to the Western European bureaucrats and intellectuals that the continent is not post-Christian and certainly not post-religious. The dismissive attitude towards the churches has led many Europeans to a contemptuous dismissal of any and all religion. Danish newspaper editors may, on the evidence, be judged to be just as guilty. In dismissing religion, many Europeans have now found themselves in a position where they simply cannot understand why Muslims would be offended by the cartoons. They do not comprehend the central role Islam plays in the lives of Muslim migrants, or of Muslims anywhere. By turning their backs on their own religious heritage, European intellectuals have stripped themselves of the ability to understand the importance of other religions to other people. They have also denied themselves the ability to understand how their own actions can cause offence. To pretend that religion has gone from the world or that it does not play a central

150 PACIFIC JOURNALISM REVIEW 12 (1) 2006 
role in the lives of billions of people around the globe is not just arrogance, it is stupidity. To proclaim that Europe is 'post-Christian' is to invite the thought that the rest of the world must be equally secular and to invite disaster when one's assumptions turn into the thoughtless indulgence of a few cartoons in a Danish newspaper.

My second point concerns the nature of the reaction to the cartoons in several Muslim countries. The cartoons were considered offensive because, in the majority sunni tradition of Islam, it is forbidden to depict any of the Prophets. ${ }^{2}$ A strict interpretation of this rule makes it haram (forbidden by Allah) to depict any living thing, although this has often been relaxed to allow for the depiction of leaves or vines. In the minority shia tradition (as practised in Iran) this sanction has not always been applied. There are many surviving examples of medieval shia art depicting the Prophet Mohammed, sometimes showing his face and hands, but sometimes with only a blank space where his face would be. Some images of the Prophet also occur in manuscripts originating in Turkey during the Ottoman empire.

In shia Iran it is apparently possible to buy paintings of the Prophet Mohammed as a boy, because of a fatwa (ruling) that he was not then the Prophet. Such Jesuitical interpretations of the law also explain why at St Joseph's Catholic church in Abu Dhabi in the UAE (which is predominantly sunni), there is a large painting behind the altar which Muslim visitors may interpret as showing the young Prophet Issa (Jesus) being led through the desert by his father, a perfectly innocuous and acceptable image, since Issa was not yet a prophet and his father was a normal man. If the thousands of Catholics who attend mass every week wish to interpret the painting as showing a mature Jesus guiding a child, then that is their business.

Such niceties of interpretation, however, are not possible with the Danish cartoons. The explanation given out by the paper's editor is that they were a reaction to the fact that a local author could not find an artist willing to provide him illustrations of the Prophet for a book about the Prophet's life for fear of retribution from Islamic extremists. The editor reasoned that this was a serious matter involving freedom of expression. He then asked 12 cartoonists to provide illustrations of the Prophet. One or two are innocuous; indeed to a non-Muslim the image of the Prophet as a simple man leading a donkey is rather nice. However, if you are a Muslim who believes that all depictions of all prophets are haram, then even these are unacceptable.

The rest of the cartoons are offensive and clearly meant to be so. If the 
editor had wanted to make a point about freedom of expression, then it could just as easily have been made in another way. However, the Jyllands-Posten cartoons were deliberately inflammatory, linking the Prophet with suicide bombings and terrorism.

Now, the link between Islam and terrorism, or between any religion and violence carried out in its name, is a proper matter for debate. It is one that should occur. Indeed, Karen Armstrong has written an extremely good book, The battle for God, which in part soberly considers the relationship between violence and fundamentalism in Islam, Christianity and Judaism. (Armstrong, 2001) There is an equal need for study of the frightening fringe dwellers of Hindu thought and of why successive Indian governments have failed to do anything about the destruction of the Ayodyah mosque. ${ }^{4}$ An attendant aspect is the issue of shame and honour in Muslim culture. Prophet Mohammed is the most honoured figure in Islam and to insult him is to insult the messenger of God. Such an insult brings shame upon Islam and the entire umma and has to be avenged in order to restore honour.

Any study of these issues must be sober and well informed if we are not to be led astray by cliches and misunderstandings. The British philosopher Roger Scruton was right when he cautioned that our images of the terrorists who claim to kill in the name of Islam must be understood to be a very modern phenomenon. ${ }^{7}$ The Jyllands-Posten did not start such a debate. No matter what its intentions, the cartoons displayed such contempt for Islam that it could not possibly make any claim to be seeking to engage in any form of dialogue. Nor can this be defended as an issue of free expression. Such debates require calm debate and a rational analysis of the issues. By depicting prophet Mohammed in such an insulting manner, Jyllands-Posten clearly showed that it was not acting in the good faith needed for such debates.

How should the world deal with this situation? If Muslims have suffered such a great insult, is it fair to ask that they contain their anger and engage instead in an intellectual discussion of the issues with the West? Ultimately, that mauy be the only solution - that and a great deal of tolerance, patience and understanding on both sides. The reaction to the controversy by Muslims with which most Westerners are familiar are the protests that take place after Friday prayers. These frequently degenerate into violence and attacks on embassies and Western franchises. The problem is that by staging such violent demonstrations, those Muslims who take part are presenting the Western world with exactly the images they fear the most: Screaming crowds, burning build- 
ings and apparently uncontrolled mobs driven mad by religious mania.

All this does is to convince Europeans that Muslims as a whole are dangerous religious fanatics with whom any dialogue is impossible. It is no wonder that the opposition to Dubai Ports' acquisition of a handful of American harbours and the EU's reluctance to supply any more funds to the Palestinian Authority has come in the wake of these incidents. Muslims could regain the moral high ground by showing themselves willing to forgive the stupidities of one Danish newspaper and instead seek to establish a dialogue that would set out new ground rules for religious tolerance and respect. If Muslim leaders are to proclaim Islam to be a religion of tolerance then that tolerance must at times be extended to those who say and do hurtful things. Neither the violence of mobs nor the scorn of secularists are measures of tolerance.

\section{Coda}

Since this article was written, the boycott of Danish products in the Middle East has eased and Danish butter is back on the shelves. The boycott has cost Danish companies millions of euros. The losses have forced the Danish dairy farm Arla to lay off 50 employees in its Saudi Arabian plant. In early April, a group of Danish students met with their Emirati counterparts at a conference in Abu Dhabi to discuss the cartoon issue. (Cartoon controversy discussed, 2006; Danish products back on shelves, 2006; Danish firm Arla to lay off employees due to boycott, 2006).

\section{Rare opportunity for education}

THE CARTOONS have been reprinted in many newspapers around the world. Sometimes it has been done because newspapers have seen it as an issue of free speech. Reactions have sometimes been violent, but not always. When the Philadelphia Inquirer decided to run one of the cartoons they did so, they said, to explain what the controversy was about. The newspaper was picketed the next day, but peacefully. The protestors did not throw rocks. Instead, they handed out copies of the Quran. As one of them told editor Amanda Bennett: 'In my eyes there is no "clash of civilizations". Rather, we are all brothers and sisters living together - each with a wealth of knowledge and experience to learn from. The Muslim community and the media have been provided a rare opportunity which is not to be missed to educate the masses and readers to the majority of Muslim popular opinion.' (Bennett, 2006). 


\section{Notes}

1 www.zombietime.com/mohammed_image_archive/

2 As with much of Islamic tradition, this injunction against graven images owes much to Mosaic law as laid down in the Old Testament, specifically Exodus 20:3-5 and Deuteronomy 5:6-10. In the Qur'an, Sura 21:51-71 can easily be interpreted as a condemnation of graven images per se, but might be interpreted more liberally to condemn only their worship, not their creation. There are schools of Islamic thought which contend that images can be halal (approved by God) depending on the use to which they are put, particularly if that use is educational. www.alsunnah.ca/

3 Tully, M. (2005). Eyewitness: Ayodhya destruction, at http://news.bbc.co.uk/2/ hi/south_asia/4651619.stm

4 As Roger Scruton puts it: '...the techniques and infrastructure on which Al Qa'eda depends are the gifts of the new global institutions. It is Wall Street and Zurich that produced the networks of international finance that enables Osama bin Laden to conceal his wealth and to deploy it anywhere in the world. It is Western enterprise...that produces the technology that bin Laden has exploited so effectively against us.' Scruton, R. (2002). The West and the Rest: London: Continuum, London, p.128.

\section{References}

'Abdullah Yusuf Ali. (1991). The meaning of the Holy Qur'an. Brentwood: Amana. Armstrong, K. (2001). The battle for God. New York: Ballantine.

Bennett, A. (2006, March 7). In cartoon debate, a chance to educate. The Philadelphia Inquirer (US).

Cartoon controversy discussed. (2006, April 16). Gulf News (UAE).

Danish products back on shelves. (2006, April 4). Gulf News (UAE).

Danish firm Arla to lay off 50 employees due to boycott. (2006, April 12). Gulf News (UAE).

Dubai sacks US prof. (2006, March 12). Arab Times (Kuwait).

NZ newspapers spark criticism by publishing cartoons. (2006, February 4). Sydney Morning Herald.

Professor and supervisor sacked. (2006, February 9). Gulf News (UAE).

Scruton, R. (2002). The West and the rest. London: Continuum.

The New American Bible. (1971). New York: Catholic Biblical Association of America/ Thomas Nelson.

Tully, M. (Year?). Eyewitness: Ayodhya destruction. At http://news.bbc.co.uk/2/hi/ south_asia/4651619.stm

Philip Cass is assistant dean of the College of Communication and Media Sciences at Zayed University in Abu Dhabi. His review of two books about the Arabic satellite news channel Al Jazeera is on pages 176-182.

philip.cass@zu.ac.uae

154 PACIFIC JOURNALISM REVIEW 12 (1) 2006 